Een kwart eeuw V.A.G.A., Jubileumboek als blijvende herinnering aan het 5 de lustrum .............................................................

(A quarter of a century V.A.G.A. (association of Universitytaught accountants), Jubilee book in lasting remembrance of the 5th lustrum)

$$
\text { door G. P. J. Hogeweg }
$$

Familie-naamloze vennootschappen van $A$. van Keulen

blz. 409

Private companies with limited liability by $A$. van Keulen)

door $M r$ A. Th. E. Kastein

Het ponskaartensysteem en enkele toepassingen van A. P. J. Pronk ...

blz. 411

(The punchcard system and some applications by A. P. J. Pronk)

door J. van Raalte

Repertorium van tijdschriftliteratuur op het gebied van accountancy en bedrijishuishoudkunde

(Literature abstracts from periodicals in the field of accountancy and business economics)

blz. 408

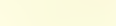

blz. 412

\title{
DE OPENBARE ACCOUNTANTS EN DE FISCUS
}

\section{door Drs W. I. van Doorn}

Reeds veel is er geschreven en gesproken over de verhouding van de openbare accountant ten opzichte van de overheidsaccountant en over de al of niet-toelaatbaarheid van het zijn van openbare accountant én belastingconsulent. De beschouwingen hierover zijn vrijwel steeds gekomen van de zijde van de openbare accountants; het leek mij daarom eens nuttig ditmaal het gezichtspunt van de fiscus, van de fiscale ambtenaren, naar voren te brengen. Het is niet mijn bedoeling om een min of meer academische beschouwing te geven, doch slechts enige opmerkingen te maken over het optreden van de openbare accountant als belastingconsulent. Ik aanvaard hierbij dus een bestaande toestand, welke al dan niet theoretisch juist te noemen is. Wel kan ik bespreken hoe deze toestand in de praktijk voldoet en welke problemen zich hierbij kunnen voordoen.

Men dient zich wel te realiseren dat van hen die optreden als accountant-belastingconsulent, het overgrote deel geen lid is van de Vaga of van het Niva. Deze groep "anderen" is zeer groot. Zowel in als na de oorlog voelden velen zich geroepen op te treden als accountant-belastingconsulent, doch slechts weinige van hen bleken in staat te zijn het door hen begonnen werk op de juiste wijze te verrichten. Dat toch zo velen hun brood konden (blijven) verdienen, is echter niet verwonderlijk omdat zij vrijwel steeds meer van de belastingwetten afwisten dan hun opdrachtgevers. En de zeer grote moeilijkheden, welke de huidige belastingwetgeving met zich medebrengt, zijn er de oorzaak van dat er vrijwel geen afgifte van enige omvang gedaan wordt zonder de hulp van een belastingadviseur.

De toestand was (en is nog) zo dat vele zakenmensen hun jaarrekeningen laten opstellen (al dan niet na contrôle) door een accountant-belastingadviseur, die daarna de aangiften voor vennootschaps- en/of inkomstenbelasting verzorgt. De fiscale ambtenaren komen daardoor met vele 
adviseurs in aanraking, waarbij dan zeer vaak blijkt dat laatstgenoemden lang niet allen de stof, welke zij moeten behandelen, zowel theoretisch als feitelijk, beheersen. Vele mededelingen worden dan ook door deze adviseurs gedaan, welke na onderzoek onvolledig blijken te zijn en bovendien, onder meer door onvoldoende controle, vaak in strijd met de waarheid.

Het is daarom niet te verwonderen dat de fiscale ambtenaren blijk geven en moeten geven van een zeker wantrouwen tegenover cijfers, verklaringen enz. van accountants-belastingconsulenten. En menigmaal is dan ook de fiscale ambtenaren toegevoegd: Ik begrijp niet dat U na al Uw droevige ervaringen nog niet veel wantrouwender bent.

Zou men echter enkele dag- en weekbladen, en niet te vergeten de radio, moeten geloven, zo is op de fiscale ambtenaren het gezegde van Tijl Uilenspiegel van toepassing: de mensen mogen mij niet, maar ik heb het er ook naar gemaakt. Ik wil zeker niet ontkennen dat ook door de fiscus fouten gemaakt zijn en worden en dat lang niet alle ambtenaren engelen in mensengedaante zijn; ook ambtenaren zijn mensen en hebben dus gebreken. Van de zijde van de fiscus wordt er naar gestreefd, dat ambtenaren zich houden aan de wetten en bepalingen en dat zij tenslotte menselijk blijven. Een volmaakt ambtenarencorps en volmaakte fiscale wetten zullen echter wel een vrome wens blijven.

Juist omdat, zoals ik hiervoor reeds schreef, de Vaga- en Nivaleden, die als belastingconsulent optreden, een zeer kleine minderheid vormen, zou het belangrijk zijn, als hun werk steeds te aanvaarden is, al zou het alleen slechts om de cijfers en toelichtingen gaan. Het moet helaas echter gezegd worden, dat dit niet het geval is en dat velen ernstig tekort schieten bij hun werk als belastingconsulent. Het is daarom geenszins verwonderlijk dat een groot deel van de fiscale ambtenaren even critisch staat tegenover de werkzaamheden in belastingaangelegenheden van Vagaen Nivaleden als tegenover die van anderen. Het is nu eenmaal zo, dat door welke oorzaken dan ook, grote drukte, te weinig personeel enz., dit werk van vele kantoren de toets van een normale critiek niet steeds kan doorstaan. Het komt betrekkelijk weinig voor, dat door de fiscus gezegd kan worden: ,de aan mij verstrekte cijfers en toelichtingen zijn zonder meer aanvaardbaar, er kunnen zich slechts principiële kwesties voordoen".

En juist met deze toestand voor ogen, zou ik enkele punten willen aangeven, welke er toe zouden kunnen leiden, dat hierin verandering komt. Ik kan hierbij slechts mijn persoonlijke opvatting weergeven, daar ik mij er van bewust ben, dat mijn mening niet door allen aanvaard zal worden.

$\mathrm{B}_{\mathrm{ij}}$ het doen van aangiften voor de belastingen $z$ ijn verschillende mogelijkheden aanwezig.

\section{a. Volledige controle met aangiften.}

De meest wenselijke toestand is dat de openbare accountant de volledige contrôle heeft van het bedrijf. De jaarrekening wordt door hem ondertekend en daarna volgen de werkzaamheden voor de aangiften. Men moet er zich wel van bewust zijn dat de accountantsverklaring betreffende de commerciële balans, naar veler mening, niet geldt voor de fiscus, daar deze balans een aantal stille reserves kan bevatten, welke fiscaal niet aanvaardbaar zijn. De maatstaven voor het maatschappelijke verkeer zijn nu eenmal geheel anders dan die voor fiscale doeleinden. De accountant zal derhalve de commerciële balans tot een fiscale balans moeten omwerken. 
Heeft hij in zijn rapport een voorbehoud gemaakt, zo moet dit ook tot uiting komen bij de door hem opgestelde en ondertekende fiscale balans. Dit laatste mist men juist in de praktijk heel vaak. Uit de aangiften zou men dan afleiden dat er ten aanzien van geen enkel punt een voorbehoud gemaakt is en bij contrôle, b.v. door de Rijksaccountantsdienst, komt aan het licht, dat de accountant voor de juistheid van de cijfers niet volledig kan instaan.

\section{b. Volledige contrōle zonder aangiften.}

Wordt de onderneming volledig gecontroleerd door de accountant, doch de directie verzorgt zelf, al dan niet met behulp van een belastingadviseur, de aangiften, zo moet de accountant er voor waken, dat wanneer hem door de directie vragen van de fiscus worden overgelegd over balanscijfers, zijn antwoord zonder meer wordt doorgegeven.

Men kan hier een vergelijking maken met de blinde accountantsverklaring. In het jaarverslag van het Niva over 1950/51 (zie De Accountant van November 1951) wordt hierover opgemerkt dat, het bestlur van de Vaga en het Niva zich hierover beraden hebben en dat zij zich op het standpunt stellen dat deze verklaringen ongewenst zijn. ,De accountant behoort zelf mededeling te doen van het resultaat van zijn arbeid, doch bovendien behoort hij gevrijwaard te zijn voor moeilijkheden, welke zouden kunnen rijzen, indien omtrent het resultaat van zijn arbeid door anderen onjuiste mededelingen zouden worden gedaan". Ik ben zelfs van mening dat het aanbeveling verdient, gezien het grote belang dat de fiscus in elke onderneming heeft, dat in de accountantsverklaring bij de commerciële balans wordt opgenomen de mededeling dat deze balans zo zonder meer niet voor fiscale aangelegenheden te gebruiken is.

\section{c. Aangiften zonder contróle.}

Tenslotte kent men in de praktijk nog veelvuldig het geval dat de openbare accountant als belastingadviseur optreedt, zonder dat hij de volledige contrôle heeft. Men hoort hierbij in hoofdzaak twee motieven noemen en wel in de eerste plaats dat de accountant hoopt op den duur de volledige contrôle te verkrijgen en voorts dat wanneer hij niet de belastingkwesties behandelt er altijd de mogelijkheid bestaat dat de cliënt in handen valt van één of andere would-be-deskundige met alle gevolgen van dien. De al of niet wenselijkheid van deze toestand zal ik niet verder bespreken, doch ik zal mij uitsluitend met de praktische kanten bezighouden, al wil ik wel hierbij opmerken dat in feite de accountant in strijd kan komen met de Voorschriften voor de Beroepsuitoefening of het Reglement van Arbeid.

Ik geloof niet dat er in de praktijk bezwaren zullen rijzen indien de accountant bij elke aangifte duidelijk laat uitkomen dat hij niet de volledige contrōle heeft en dat hij dus niet kan instaan voor de volledige juistheid. Ook dit wordt in de praktijk vaak onvoldoende tot uitdrukking gebracht. Ernstige bezwaren heb ik tegen het gebruik van de zinsnede: Nadere inlichtingen worden desgewenst gaarne verstrekt door ............. speciaal in die gevallen waarin de accountant geen volledige contrôle heeft en hij dit op de aangiften niet vermeldt. De aangehaalde zin suggereert dat men alle inlichtingen, dus ook over de bijgevoegde jaarrekening, kan verkrijgen, terwijl dit in werkelijkheid niet het geval is.

De grote moeilijkheid voor de rijksaccountants is, dat, wanneer zij 
ernstige overtredingen van accountants bemerken, zij hiertegen zo weinig kunnen doen, daar hun dit door hun beroepsgeheim onmogelijk gemaakt wordt. Slechts de Minister kan hun toestaan bij de Raad van Tucht een klacht in te dienen. Gevallen waarin deze toestemming gegeven is, zijn mij niet bekend. Zou het nu niet op de weg van de besturen van de Vaga en Niva liggen om er bij de Minister op aan te dringen, toestemming te geven aan de hoofden van bureaux van de Rijksaccountantsdienst om in gevallen van ernstige aard een klacht in te dienen bij de Raad van Tucht. De beoordeling wordt dan in handen gelegd van oudere accountants, vrijwel steeds leden van de Vaga of het Niva, die zeker tot beoordeling bevoegd zijn. Ik geloof dat een dergelijke mogelijkheid zeker zal leiden tot een verbetering van de bestaande toestanden.

Een maatregel, welke wel bestaat, is het niet meer toelaten tot de inspecties van accountants, die ernstige onjuistheden begaan hebben. Hier ligt de beoordeling echter bij niet-vakgenoten, die voorts meestal onvoldoende op de hoogte zijn van normen waaraan het werk van accountants moet voldoen. Bovendien wordt door allerlei omstandigheden deze maatregel weinig toegepast.

Ik moge mijn beschouwing eindigen met de volgende opmerkingen. Ik heb met opzet geen principiële kwesties behandeld, omdat ik meen dat de verschillende gevallen al voldoende en door meer tot oordelen bevoegden behandeld zijn. Ik wilde uitsluitend meer het licht laten vallen op enkele problemen, welke zich in de praktijk voordoen en daarbij tevens, zo mogelijk, enige richtlijnen aangeven, welke tot verbetering kunnen leiden. Voor de ouderen onder de lezers zal ik weinig nieuw geluid hebben laten horen, doch ik hoop speciaal de aandacht van de jongeren op een aantal praktijkkwesties te hebben gevestigd. Moge dit er toe bijdragen dat het optreden van de accountants, leden van de Vaga en het Niva, als belastingconsulent, in de naaste toekomst een belangrijke verbetering ondergaat. 